Prepared in cooperation with the New Jersey Department of Environmental Protection

\title{
Bathymetry of Morris Lake (Newton Reservoir), New Jersey, 2018
}

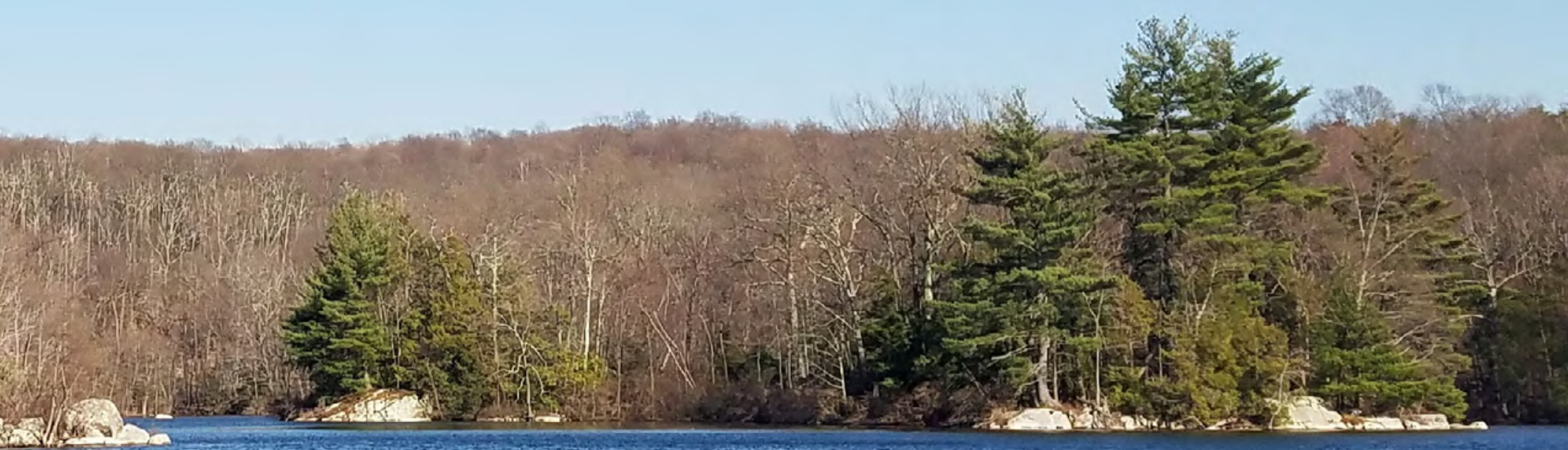

Seienifile /ivestigations Report $2020=5010$

US Department of the interior

U.S: Geological Sulvey 
Cover. Morris Lake, New Jersey, viewed from survey boat. Photograph by Elizabeth Nystrom, U.S. Geological Survey. 


\section{Bathymetry of Morris Lake (Newton Reservoir), New Jersey, 2018}

By Elizabeth A. Nystrom and Jerilyn V. Collenburg

Prepared in cooperation with the

New Jersey Department of Environmental Protection

Scientific Investigations Report 2020-5010 


\title{
U.S. Department of the Interior \\ DAVID BERNHARDT, Secretary
}

\author{
U.S. Geological Survey \\ James F. Reilly II, Director
}

U.S. Geological Survey, Reston, Virginia: 2020

For more information on the USGS - the Federal source for science about the Earth, its natural and living resources, natural hazards, and the environment—visit https://www.usgs.gov or call 1-888-ASK-USGS.

For an overview of USGS information products, including maps, imagery, and publications, visit https://store.usgs.gov/.

Any use of trade, firm, or product names is for descriptive purposes only and does not imply endorsement by the U.S. Government.

Although this information product, for the most part, is in the public domain, it also may contain copyrighted materials as noted in the text. Permission to reproduce copyrighted items must be secured from the copyright owner.

Suggested citation:

Nystrom, E.A., and Collenburg, J.V., 2020, Bathymetry of Morris Lake (Newton Reservoir), New Jersey, 2018:

U.S. Geological Survey Scientific Investigations Report 2020-5010, 14 p., https://doi.org/10.3133/sir20205010.

Associated data for this publication:

Nystrom, E.A., and Collenburg, J.V., 2020, Geospatial bathymetry dataset and elevation-area-capacity table for Morris Lake (Newton Reservoir), New Jersey: U.S. Geological Survey data release, https://doi.org/10.5066/P977G03J.

ISSN 2328-0328 (online) 


\section{Acknowledgments}

The authors would especially like to thank Jack Smalley, operator of the filtration plant at Morris Lake, for his assistance and hospitality during our time on the lake. The authors would like to acknowledge the assistance provided by several colleagues at the U.S. Geological Survey (USGS) New Jersey Water Science Center: Karl M. Braun, for operating the boat and other supporting field work; Jason C. Shvanda for supporting field and office work; and Thomas P. Suro for technical assistance. 



\section{Contents}

Acknowledgments ……...................................................................................................................

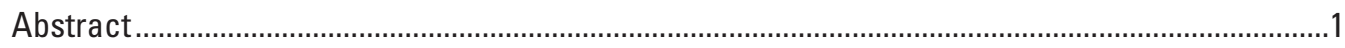

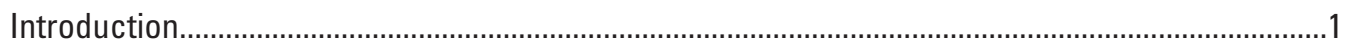

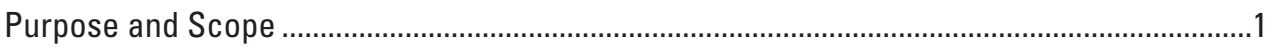

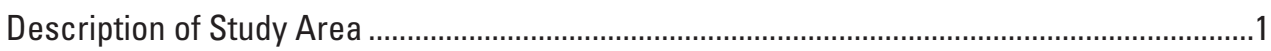

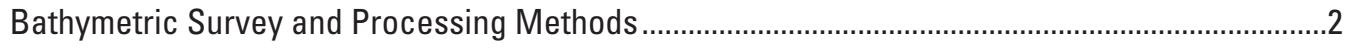

Vertical Control and Water Surface Elevation ...........................................................................

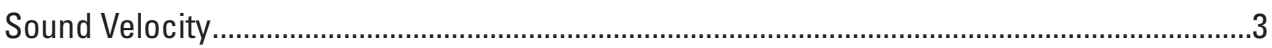

Multibeam Echosounder ........................................................................................................

Quality Assurance Dataset: Single-Beam Echosounder ...........................................................

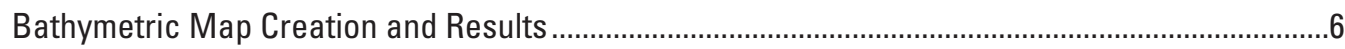

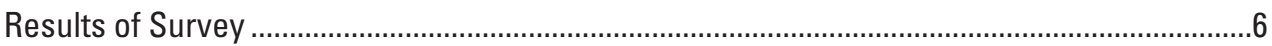

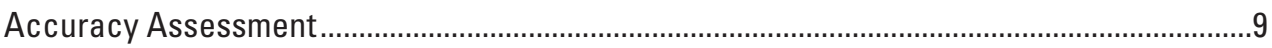

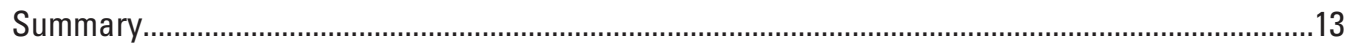

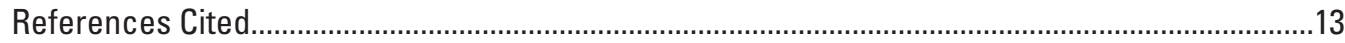

\section{Figures}

1. Map showing location of Morris Lake (Newton Reservoir) in New Jersey .......................2

2. Photograph of survey boat and global navigation satellite system rover receiver used for the bathymetric survey of Morris Lake (Newton Reservoir), New Jersey...........3

3. Graph showing sound velocity profiles, including measured values and processing average for Morris Lake (Newton Reservoir), New Jersey .............................

4. Photograph of multibeam echosounder …………........................................................

5. Photograph of single-beam echosounder ……...........................................................

6. Map showing interpolated areas and mapped bathymetric depths and depth contours of Morris Lake (Newton Reservoir), New Jersey.................................................7

7. Map showing bathymetric elevations and elevation contours of Morris Lake (Newton Reservoir), New Jersey, and elevations of surrounding area ............................8

8. Map showing quality assurance echosounder points compared to mapped elevation and slope of bathymetric surface, Morris Lake (Newton Reservoir), New Jersey.

9. Graph showing results of comparison of quality assurance points and mapped surface by depth and slope

10. Illustration of echosounder beam geometry and potential cause of errors on steep slopes 


\section{Tables}

1. Results of bar check, April 23, 2018, Morris Lake (Newton Reservoir), New Jersey........6

2. Reservoir area and capacity at specified depths for Morris Lake (Newton Reservoir), New Jersey

3. Reservoir area and capacity at specified elevations for Morris Lake (Newton Reservoir), New Jersey

4. Accuracy of point elevations of single-beam echosounder quality assurance points compared to mapped multibeam echosounder raster surface for Morris Lake (Newton Reservoir), New Jersey, bathymetric survey..

\section{Conversion Factors}

U.S. customary units to International System of Units

\begin{tabular}{lcl}
\hline & Multiply & By obtain \\
\hline foot (ft) & Length & \\
mile (mi) & 0.3048 & meter $(\mathrm{m})$ \\
& 1.609 & kilometer $(\mathrm{km})$ \\
\hline acre & Area & \\
acre & 4,047 & square meter $\left(\mathrm{m}^{2}\right)$ \\
square mile (mi $\left.{ }^{2}\right)$ & 0.004047 & square kilometer $\left(\mathrm{km}^{2}\right)$ \\
\hline & 2.590 & square kilometer $\left(\mathrm{km}^{2}\right)$ \\
\hline gallon (gal) & Volume & \\
gallon (gal) & 3.785 & liter $(\mathrm{L})$ \\
million gallons (Mgal) & 0.003785 & cubic meter $\left(\mathrm{m}^{3}\right)$ \\
acre-foot (acre-ft) & 3,785 & cubic meter $\left(\mathrm{m}^{3}\right)$ \\
\hline
\end{tabular}

\section{Datum}

Vertical coordinate information is referenced to the North American Vertical Datum of 1988 (NAVD 88).

Horizontal coordinate information is referenced to the North American Datum of 1983 (NAD 83).

Elevation, as used in this report, refers to distance above the vertical datum. 


\section{Abbreviations}

$\begin{array}{ll}\text { FGDC } & \text { Federal Geographic Data Committee } \\ \text { GIS } & \text { geographic information system } \\ \text { GNSS } & \text { global navigation satellite system } \\ \text { INS } & \text { inertial navigation system } \\ \text { kHz } & \text { kilohertz } \\ \text { lidar } & \text { light detection and ranging } \\ \text { POS MVTM } & \text { Position Orientation Solution for Marine Vessels } \\ \text { RTK } & \text { real-time kinematic } \\ \text { RMSE } & \text { root mean square error } \\ \text { USGS } & \text { U.S. Geological Survey } \\ \text { VRS } & \text { virtual reference station network }\end{array}$





\title{
Bathymetry of Morris Lake (Newton Reservoir), New Jersey, 2018
}

\author{
By Elizabeth A. Nystrom and Jerilyn V. Collenburg
}

\section{Abstract}

Morris Lake, also known as Newton Reservoir, has been the source of drinking water for the Town of Newton, New Jersey, since the early 1900s. Although Morris Lake has been used as a source of drinking water for many years, its capacity was previously uncertain. In April 2018, the U.S. Geological Survey and the New Jersey Department of Environmental Protection conducted a bathymetric survey of Morris Lake using a multibeam echosounder to map the reservoir. The points measured with the multibeam echosounder were combined with light detection and ranging data above the water surface and processed to create a 3.3-foot (1 meter) raster grid of the bathymetric surface, bathymetric contours at 2-foot intervals of depth and elevation, and an elevation-areacapacity table.

The results of the bathymetric survey show that Morris Lake has a maximum depth of just over 119 feet with an average depth of 42 feet. Like the surrounding topography, parts of the reservoir are extremely steep. The capacity of the reservoir at full spillway level is 1,980 million gallons, with a corresponding surface area of 145 acres. The accuracy of the mapped multibeam echosounder bathymetric data was evaluated using a quality assurance dataset collected with a single-beam echosounder; 9,386 quality assurance points were spatially joined with the mapped raster surface to compute measurement errors. The calculated median point error for Morris Lake was 0.23 foot, the median absolute error was 0.35 foot, and the 95 -percent accuracy was 2.68 feet. The largest errors occurred in the steepest areas of the reservoir and in unmeasured areas. Geospatial files of the bathymetry data, including the mapped bathymetric surface, contours, and capacity tables, quality assurance points, and associated metadata are available for download as part of an accompanying U.S. Geological Survey data release.

\section{Introduction}

Morris Lake in Sparta Township, New Jersey, has been the source of drinking water for the Town of Newton since the early 1900s. Although Morris Lake has been used as a source of drinking water for many years, the depths of the reservoir and storage capacity were previously uncertain. In 2018, the U.S. Geological Survey (USGS) and the New Jersey Department of Environmental Protection conducted a bathymetric survey of Morris Lake to create a map of the bathymetric surface, to produce bathymetric contours, and to compute an elevation-area-capacity table.

\section{Purpose and Scope}

The purpose of this report is to document the results of the bathymetric survey of Morris Lake completed in April 2018 using a multibeam echosounder. Equipment and methods of data collection and processing are described and results, including data accuracy assessment, are presented.

\section{Description of Study Area}

Morris Lake, also known as the Newton Reservoir, is located in Sparta Township in the Sparta Mountains in Sussex County, New Jersey (fig. 1). According to historical documents (Dickinson, 1899), Morris Lake was originally a deep, natural lake that covered approximately 130 acres and was fed mainly by natural springs with a drainage area of about 1.25 square miles $\left(\mathrm{mi}^{2}\right)$. In the late $1700 \mathrm{~s}$, mill owners in the village of Sparta erected a several-foot-high dam across the lake's outlet. The dam increased the depth and storage of the lake, allowing the village to continue to draw water during dry conditions. Then in the mid-1800s, another dam was built approximately 0.25 mile below the lake, which formed a pond between the lake and Pine Swamp Brook (not shown on fig. 1). Eventually the pond and the lake were united when the pond was raised to the level of the first dam located at the original outlet of Morris Lake. Through damming a portion of Pine Swamp Brook, an artificial channel and smaller artificial lake were created below Morris Lake, which is now known as Glen Lake (fig. 1). The drainage area of these two lakes combined was increased to about $3.80 \mathrm{mi}^{2}$. Gates were then constructed in the dams so that they could be opened and closed to supply water to the mills in the village (Dickinson, 1899). From the late 1800s to the present (2019), Morris Lake has been supplying water to the Town of Newton, located about 7 miles from the lake. 


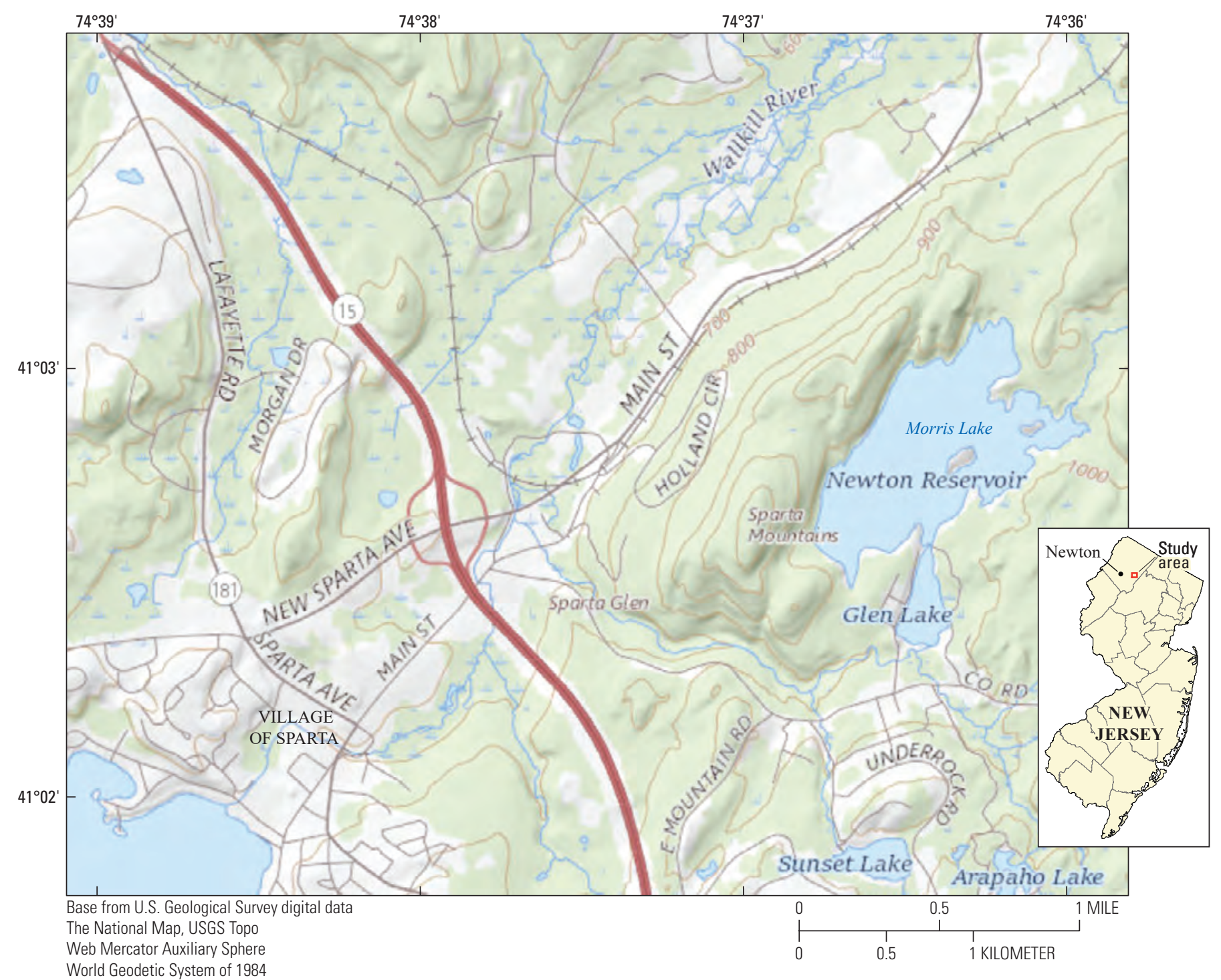

Figure 1. Location of Morris Lake (Newton Reservoir) in New Jersey.

\section{Bathymetric Survey and Processing Methods}

A bathymetric survey was conducted in April 2018 using a multibeam echosounder from a small moving boat (fig. 2). Ancillary data measured and used in processing the echosounder data included water surface elevation (for vertical position data) and sound velocity profiles at three locations in the lake. A quality assurance dataset was collected using a single-beam echosounder for comparison with the multibeam echosounder dataset. Vertical coordinate information is referenced to the North American Vertical Datum of 1988 (NAVD 88), transformed by GEOID09 (conterminous United States) to vertical datum. Horizontal coordinate information is referenced to the North American Datum of 1983 (NAD 83).

\section{Vertical Control and Water Surface Elevation}

Vertical control was established using global navigation satellite system (GNSS) surveys to determine the elevation of the spillway and establish a reference point from which to measure the water surface elevation. GNSS surveys were done utilizing a virtual reference station (VRS) network with highly precise GNSS reference stations and a survey-grade Trimble ${ }^{\circledR}$ R10 rover/receiver. The continuously operating VRS provided base stations for the survey, and once set up over an objective point, the VRS network corrected for ionospheric and other atmospheric conditions in the satellite signals to increase the accuracy of the GNSS at the survey location. Continuous real-time kinematic (RTK) and differential corrections to the GNSS horizontal and vertical positions were made using the fixed-base station VRS network operated by 


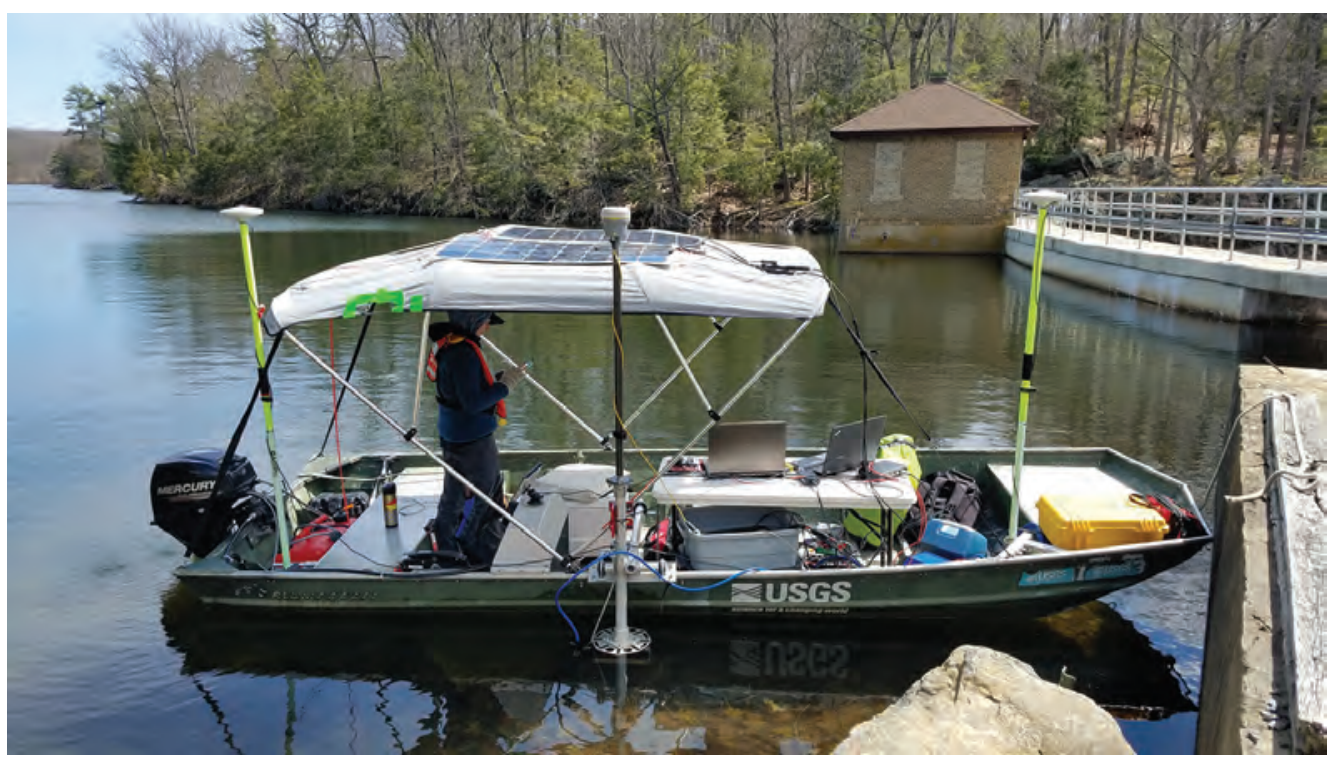

Figure 2. Survey boat and global navigation satellite system (GNSS) rover receiver used for the bathymetric survey of Morris Lake (Newton Reservoir), New Jersey. Photograph by Elizabeth Nystrom, U.S. Geological Survey.

KeyNetGPS, Inc. (2019). The survey followed the approach and methods of a Level II quality survey as described by Rydlund and Densmore (2012), including blunder checks, redundancy checks, and vertical order 2 benchmark checks before and after surveying objective points at the lake. The left and right edges of the spillway were surveyed; the average elevation of the spillway observations was 938.39 feet (ft) above NAVD 88. A reference point was also surveyed for use to relate the water surface to elevation above NAVD 88.

A time series of water surface elevation, measured using pressure transducers, was used to convert mapped bathymetric depths to elevations. An unvented pressure transducer was installed in the reservoir near the spillway; a second pressure transducer installed above the water surface was used to correct the underwater time series for changes in barometric pressure. Measured pressures were converted to depths by calculating water density using the water temperature measured by the pressure transducer. The depth time series was then converted to elevations using measurements from the reference point (two on April 23 and two on April 24; before and after daily echosounder data collection). During the survey, the water surface elevation was essentially constant, approximately 0.10 to $0.15 \mathrm{ft}$ above the spillway elevation.

\section{Sound Velocity}

Echosounders determine depth by transmitting a pulse of sound into the water and measuring the amount of time it takes for an echo to return; to accurately calculate a depth, the sound velocity must be known. Sound velocity varies with temperature, pressure, and salinity; reservoirs are often stratified by temperature, so the sound velocity usually varies with depth.
Additionally, sound velocity profiles can vary by location because surface water in shallow areas may warm differently than deep areas. To account for the change of sound velocity over depth and area, profiles were measured using an Applied Microsystems Smart SV Sensor (AML Oceanographic, 2010). Five sound velocity profiles were measured during the survey, one on April 23 and four on April 24 (fig. 3). Sound velocity profiles were measured in the deepest part of the reservoir on April 23 at 15:55 and on April 24 at 09:15 and 15:50 to record a full profile for processing; sound velocity profiles were also taken in shallower locations around the reservoir - on April 24 at 15:45 (near the north end of the reservoir) and on April 24 at 16:05 (near the south end of the reservoir) - to verify consistency of the profiles throughout the reservoir. Sound velocity was recorded at 5-ft increments from the surface to the deepest depth at the location of measurement (20 to $115 \mathrm{ft}$ ). When the profiles were plotted and examined, it was determined that a single average profile could reasonably be used for the entire survey (fig. 3); sound speed was most variable in the upper $30 \mathrm{ft}$ of the reservoir and at the water surface.

\section{Multibeam Echosounder}

A multibeam echosounder is an instrument that uses sound to measure water depths at many locations simultaneously along a particular swath. Multibeam echosounders are manufactured in many configurations, but they often use two phased-array transducers to shape acoustic transmit and receive beams and slice the acoustic returns into hundreds of individual depth measurements along each swath. To accurately map the locations of the depth measurements in space, multibeam echosounders are used with an inertial 


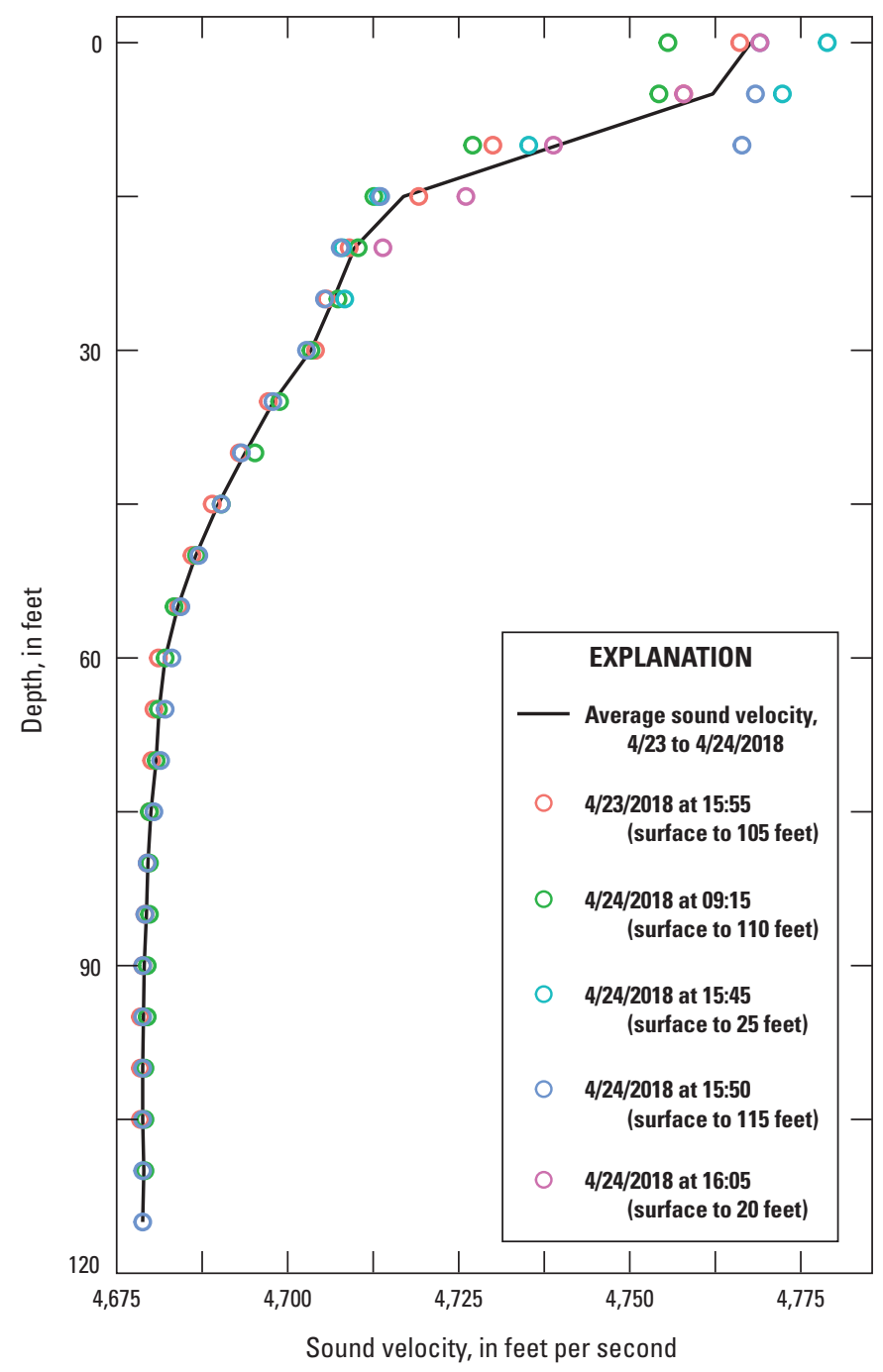

Figure 3. Sound velocity profiles, including measured values (points) and processing average (line) for Morris Lake (Newton Reservoir), New Jersey. Dates are in month/day/year format, and times are in 24-hour format.

navigation system (INS) to measure heave, pitch, roll, heading, and position. More information about multibeam echosounders and examples of their use for surveying rivers and lakes is described in Huizinga and Heimann (2018) and Huizinga (2016).

Bathymetric data were collected with a multibeam echosounder on April 24, 2018. The multibeam echosounder used for this study (fig. 4) was a Teledyne Odom Hydrographic MB2 (Teledyne Odom Hydrographic, 2019) with integrated Applanix Position Orientation Solution for Marine Vessels (POS MVTM) Wavemaster II INS (Applanix Corporation, 2017) and a Teledyne Reson SVP-70 sound velocity sensor (Teledyne RESON, 2019). The MB2 has up to 256 adjustablefrequency beams - from 200 to 460 kilohertz (kHz) — with up to a 140-degree swath width and configurable beam width (nominal beam width 1.8 degrees).
For the survey of Morris Lake, the MB2 was generally operated at $460 \mathrm{kHz}$ with 256 beams and 140-degree swath width. In some areas of the reservoir, changes to the configuration of the MB2 were made because of field conditions; for example, in areas of excessive aquatic plant growth, the frequency of the MB2 was lowered to $200 \mathrm{kHz}$ to obtain a stronger reflection from the bottom of the reservoir. The minimum depth measurable with the MB2 was approximately $2 \mathrm{ft}$. The position data from the Wavemaster II INS was supplemented with RTK GNSS position data from a Trimble R10 GNSS receiver and the VRS; this GNSS receiver was positioned directly above the echosounder transducer. Additionally, the NMEA 0183 ZDA string output by this GNSS receiver was used to time synchronize the INS and MB2 echosounder data. The MB2 echosounder data were displayed and recorded using Teledyne PDS version 4.1.5.3 (Teledyne, 2019) software. PDS creates a raster grid of raw measured depths in real time, which was used by the boat driver to navigate for the most complete coverage of the bathymetric surface possible.

The INS installed in the multibeam echosounder measures pitch, roll, heading, and heave to compute the correct location in three-dimensional space of the points measured by the MB2. To verify the performance of these measurements and to calibrate the alignment of these sensors, a patch test was performed during the morning of April 24. A patch test consists of a series of movements recorded with a multibeam echosounder over a bathymetric surface: two passes of data are collected traveling in opposite directions over a flat surface to calibrate the roll correction; two passes are collected traveling in opposite directions over a slope to calibrate the pitch correction; and two passes are collected traveling in the same direction along offset paths to calibrate the heading correction. A patch test was conducted at Morris Lake over the flat surfaces in the deepest portion of the lake and over the adjacent steep slope along the northwestern edge of the lake. The computed pitch correction was 0.03 degree, the roll correction was

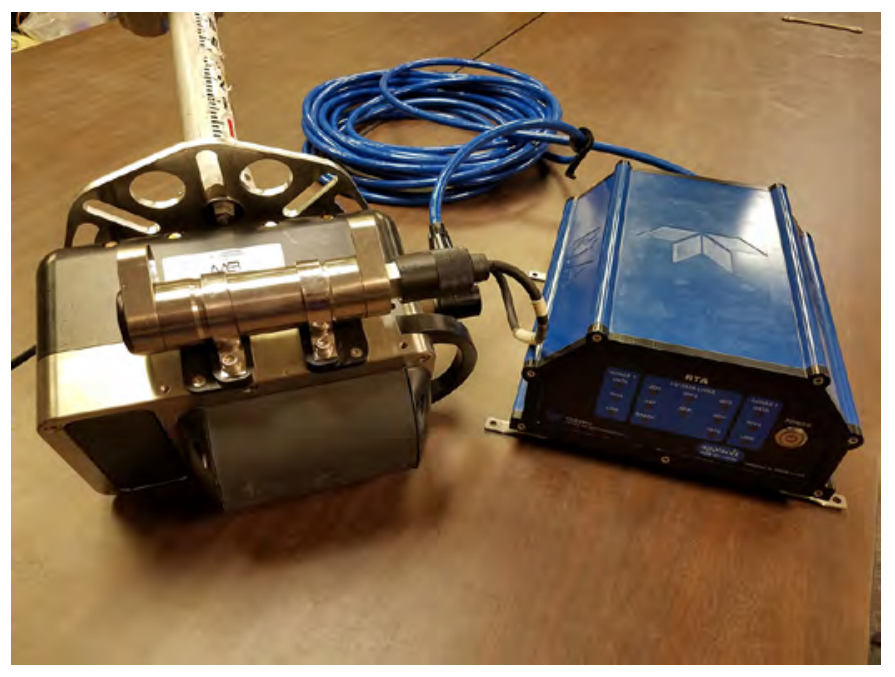

Figure 4. Multibeam echosounder. Photograph by Elizabeth Nystrom, U.S. Geological Survey. 
-0.05 degree, and the heading correction was -3.09 degrees. Because the POS Wavemaster II INS is permanently installed inside the MB2 transducer enclosure, the pitch, roll, and heading corrections are generally consistent over time.

The multibeam echosounder data were processed using the same software used to collect the data, Teledyne PDS version 4.1.5.3 (Teledyne, 2019). Multibeam echosounder processing included correction for changes in sound velocity over depth, conversion from depth to elevation above NAVD 88, and editing to remove erroneous points or spikes. The five measured sound velocity profiles were averaged to form a single sound velocity profile for Morris Lake. During multibeam echosounder data collection, sound velocity was also measured near the surface with the SVP-70; PDS was used to combine the time series of measurements of sound velocity at the surface with the average sound velocity profile over depth to form a time series of sound velocity profiles. Data from adjacent MB2 measurement swaths were generally spaced to overlap at the edges by 10 to 25 percent; these overlapping areas were used as an additional quality assurance check to verify reproducibility of point measurements after pitch, roll, heading, and sound velocity profile corrections.

Depths measured by the MB2 were converted to elevations above NAVD 88 using the water surface elevation as a reference. A moving average of the pressure transducer water surface elevation time series (recorded at 15-minute intervals) was computed using a 2-hour (9 observation) centered window. Depths were then subtracted from the water surface elevation time series to compute bathymetric elevations.

After correction for heading, pitch, roll, sound velocity, and conversion to elevation, multibeam echosounder point data were edited to remove erroneous data and spikes. Point editing in PDS uses filters and manual editing; filters use metadata about each return and surrounding measured points to identify spikes and points of poor quality, which are then reviewed and removed. Manual editing was largely used to remove points recorded above the reservoir bottom when the acoustic signal was reflected off aquatic plants. The MB2 recorded 476,515 swaths (each a single observation in time with up to 256 point observations), for a total of $121,987,840$ possible points recorded. Of the possible points, 58.6 percent were rejected by filters and manual editing, including 48.7 percent that were rejected by the echosounder's quality filter, many in areas of dense aquatic plant growth, resulting in a total of 50,466,514 valid point observations after editing.

\section{Quality Assurance Dataset: Single-Beam Echosounder}

Bathymetric data were collected with a single-beam echosounder on April 23, 2018, for use as a quality-assurance check of the mapped multibeam echosounder data. The single-beam echosounder used for this study was a SyQwest Bathy-500 MF (fig. 5), a survey-grade echosounder with a resolution of $0.1 \mathrm{ft}$ and a manufacturer-specified accuracy of $0.1 \mathrm{ft}$ plus 0.1 percent of the depth (SyQwest, Inc., 2008). A 200-kHz narrow-beam transducer (3 degrees at 3 decibels) was used; the minimum measurable depth with this configuration was approximately $3 \mathrm{ft}$. Position data were measured using the Trimble R10 GNSS receiver with VRS RTK corrections; the GNSS receiver was mounted directly above the single-beam transducer during data collection. Pitch and roll were not recorded or used in processing the single-beam echosounder data, but the transducer was leveled on the boat using a bubble level attached to the transducer mount; errors in alignment of the transducer or changes in tilt of the boat while under way can therefore contribute to errors in measurement of depth with the single-beam echosounder.

Live echosounder readings and RTK-GNSS position data were integrated in the field using the hydrographic software HYPACK ${ }^{\circledR}$ (HYPACK, Inc., 2019), which used the NMEA 0183 ZDA message in the GNSS data string to time synchronize position and depth data. Single-beam echosounder data were collected along predetermined lines, spaced approximately $350 \mathrm{ft}$ apart at a 45 -degree angle to the main axis of the reservoir; the goal of the spacing was to record data along 10 or more lines from edge to edge of the reservoir. The configuration of these quality assurance lines followed procedures similar to those used by Wilson and Richards (2006).

Single-beam echosounder depth measurement was checked by performing a bar check, a process in which a bar or plate is suspended at a known depth below the echosounder and the depth measured from the echo return off the bar is then compared to the known depth of the bar. A 3-ft by 4-ft perforated aluminum plate was lowered into the reservoir below the single-beam echosounder to specified depths at 5-ft intervals from $5 \mathrm{ft}$ to $25 \mathrm{ft}$ to verify live echosounder readings. The bar check was performed at the start of data collection on April 23 (table 1).

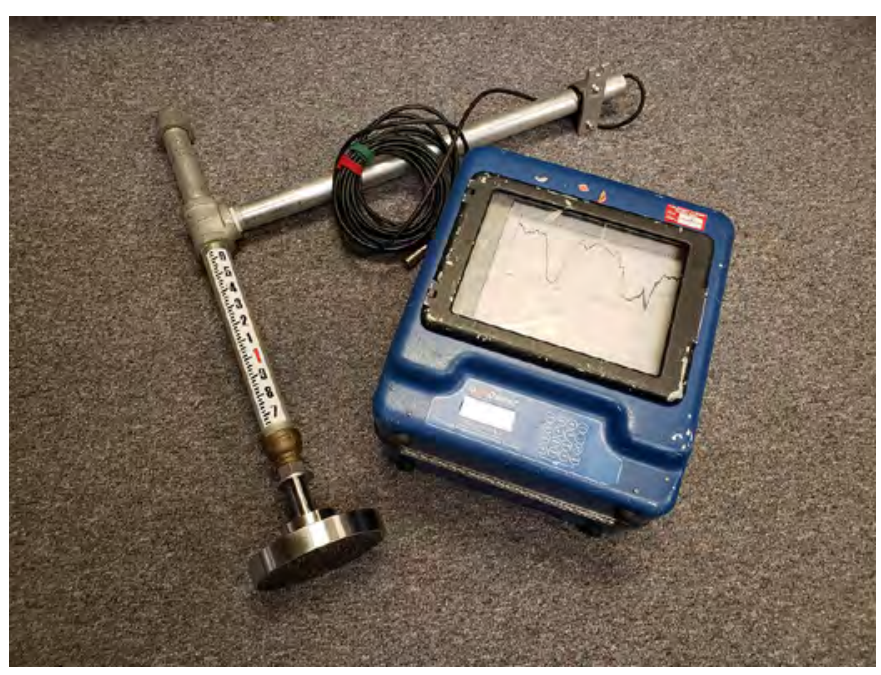

Figure 5. Single-beam echosounder. Photograph by Elizabeth Nystrom, U.S. Geological Survey. 
Table 1. Results of bar check, April 23, 2018, Morris Lake (Newton Reservoir), New Jersey.

[Location of reservoir shown in figure 1]

\begin{tabular}{cccc}
\hline Depth of bar, in feet & Raw recorded depth, in feet & Sound speed correction, in feet & Final corrected depth, in feet \\
\hline 5 & 4.7 & 0.05 & 4.75 \\
10 & 9.9 & 0.10 & 10.00 \\
15 & 14.6 & 0.12 & 14.72 \\
20 & 19.9 & 0.13 & 20.03 \\
25 & 24.9 & 0.13 & 25.03 \\
\hline
\end{tabular}

Single-beam echosounder data were processed using HYPACK; processing included correction for changes in sound velocity over depth, conversion from depth to elevation above NAVD 88, and manual editing to remove erroneous points or spikes. The same averaged sound velocity profile that was used to process the multibeam echosounder data was used to process the single-beam data; however, there was no time series of sound velocity at the surface. Depths measured by the single-beam echosounder were converted to elevations above NAVD 88 by using the same method as that for the multibeam echosounder, using the water surface elevation as a reference. After processing the single-beam echosounder data, 9,386 point observations remained.

\section{Bathymetric Map Creation and Results}

The processed multibeam echosounder points were used to create a raster grid bathymetric surface, bathymetric contours, and an elevation-area-capacity table. The raster grid and contours were created in PDS, and the elevation-area-capacity table was created in a geographic information system (GIS) using ArcMap (Esri, Inc., 2019).

The Grid Model Editor in PDS was used to create a 3.3-ft (1 meter) raster grid of the bathymetric surface using the average elevation of the edited points within a raster cell; the mean count of measured points within a cell was 95 . Complete ensonification of the bathymetric surface was not possible, especially in shallow areas where navigation of the boat was limited to protect the multibeam echosounder from damage and areas with excessive aquatic plants. Light detection and ranging (lidar) data (OCM Partners, 2019) with root mean square error (RMSE) of $0.61 \mathrm{ft}$ for the area surrounding the reservoir above the water surface elevation was used to supplement measured multibeam echosounder points to allow interpolation of shallow cells near the edge of the reservoir; lidar elevation values above the water surface were extracted from the 5-ft cell-size raster and were added as point values to the multibeam data. The area between the lidar and multibeam data was interpolated using the interpolate circular method in the grid editor of PDS. Additional point values were added manually to a shallow area on the east side of the lake to represent a group of large rocks identified from satellite imagery and field observations. About 11 percent of Morris Lake was not directly measured using the multibeam echosounder; mapped cells that contained no point observations (fig. 6) were interpolated using the interpolate circular method in PDS to produce a complete raster grid of Morris Lake.

Bathymetric contours were created at 2-ft intervals of depth and elevation above NAVD 88 from the 3.3 -ft raster using the Grid Model Editor in PDS. A smoothing window of 4 (medium) was used and contours less than $32.8 \mathrm{ft}$ (10 meters) long were removed. Elevation-area-capacity tables were calculated from the mapped raster surface at $0.1-\mathrm{ft}$ intervals of depth and elevation using the three-dimensional analyst surface-volume tool in ArcMap (Esri, Inc., 2019).

\section{Results of Survey}

The results of the bathymetric survey (figs. 6 and 7) show that the deepest part of Morris Lake is just over $119 \mathrm{ft}$ (maximum mapped depth $119.34 \mathrm{ft}$ ); the average depth is $42 \mathrm{ft}$. Tabular values of surface area and volume at $10-\mathrm{ft}$ intervals of depth below the spillway and elevation above NAVD 88 are shown in tables 2 and 3, respectively; the full elevation-areacapacity tables at $0.1-\mathrm{ft}$ increments of depth and elevation are available online in a USGS data release (Nystrom and Collenburg, 2020). Steep, rocky outcrops to the northwest of the reservoir continue underwater, and slopes of more than 80 degrees are present in some areas of the reservoir; other areas of the reservoir are quite flat with slopes of less than 10 degrees. At full capacity (water surface elevation equal to the elevation of the top of the spillway), the capacity of the reservoir is 1,980 million gallons and the surface area is 145 acres (table 2). The useable capacity of the reservoir, or the volume above the minimum operating level for drinking water supply, is less than the full capacity of the reservoir. GIS files of the bathymetry data including the mapped bathymetric surface, contours and capacity tables, quality assurance points, and associated metadata are available for download as digital data in Nystrom and Collenburg (2020). These digital data are presented in State Plane coordinates referenced horizontally to NAD 83 and vertically to NAVD 88. 


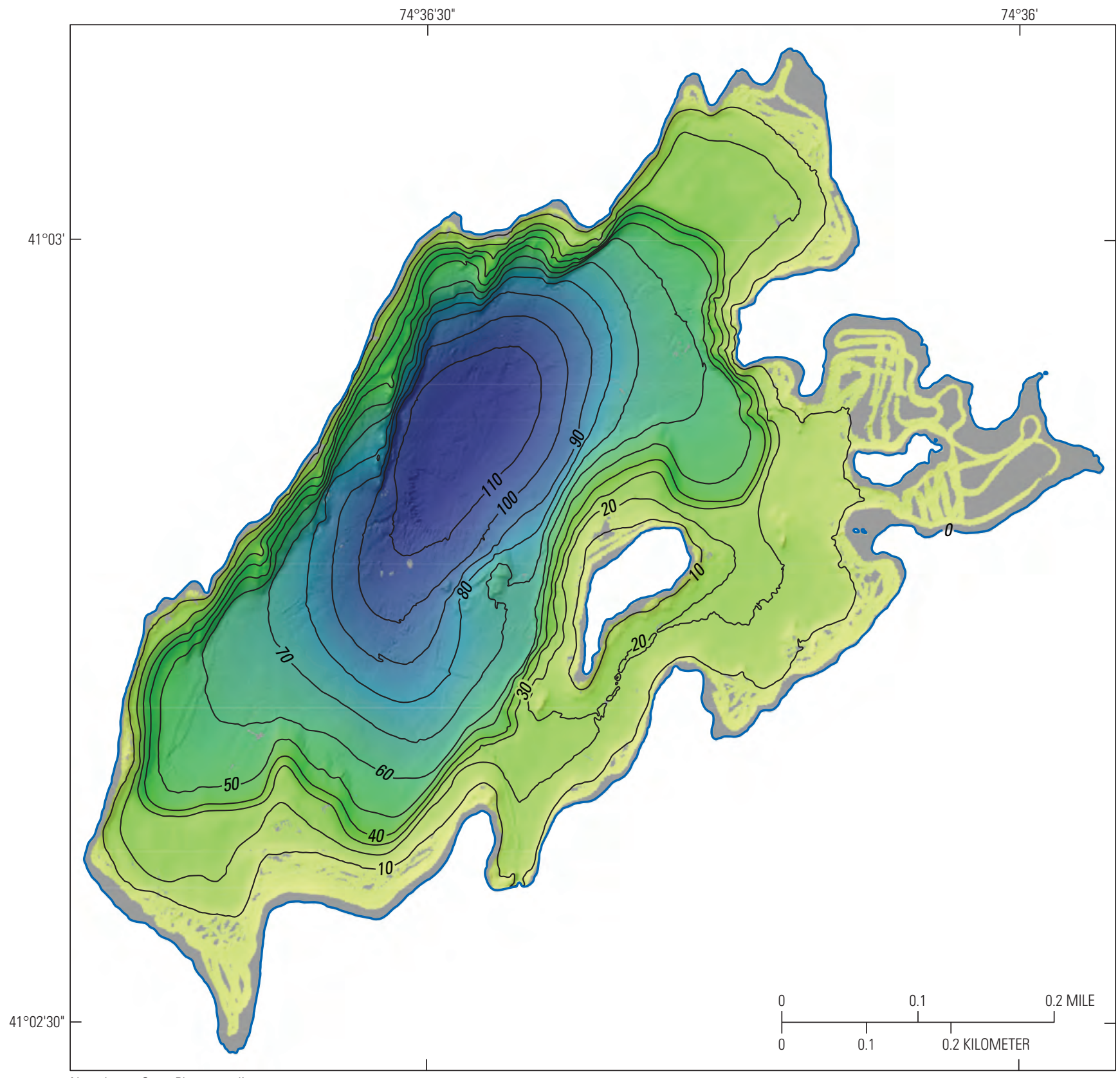

New Jersey State Plane coordinate system North American Datum of 1983

EXPLANATION

Interpolated (unmeasured) area

Depth below spillway elevation, in feet

0

60

119.3

-10 - Depth contour-Contour interval 10 feet

Morris Lake boundary-Depth contour 0 feet deep

Figure 6. Interpolated areas and mapped bathymetric depths and depth contours of Morris Lake (Newton Reservoir), New Jersey. 


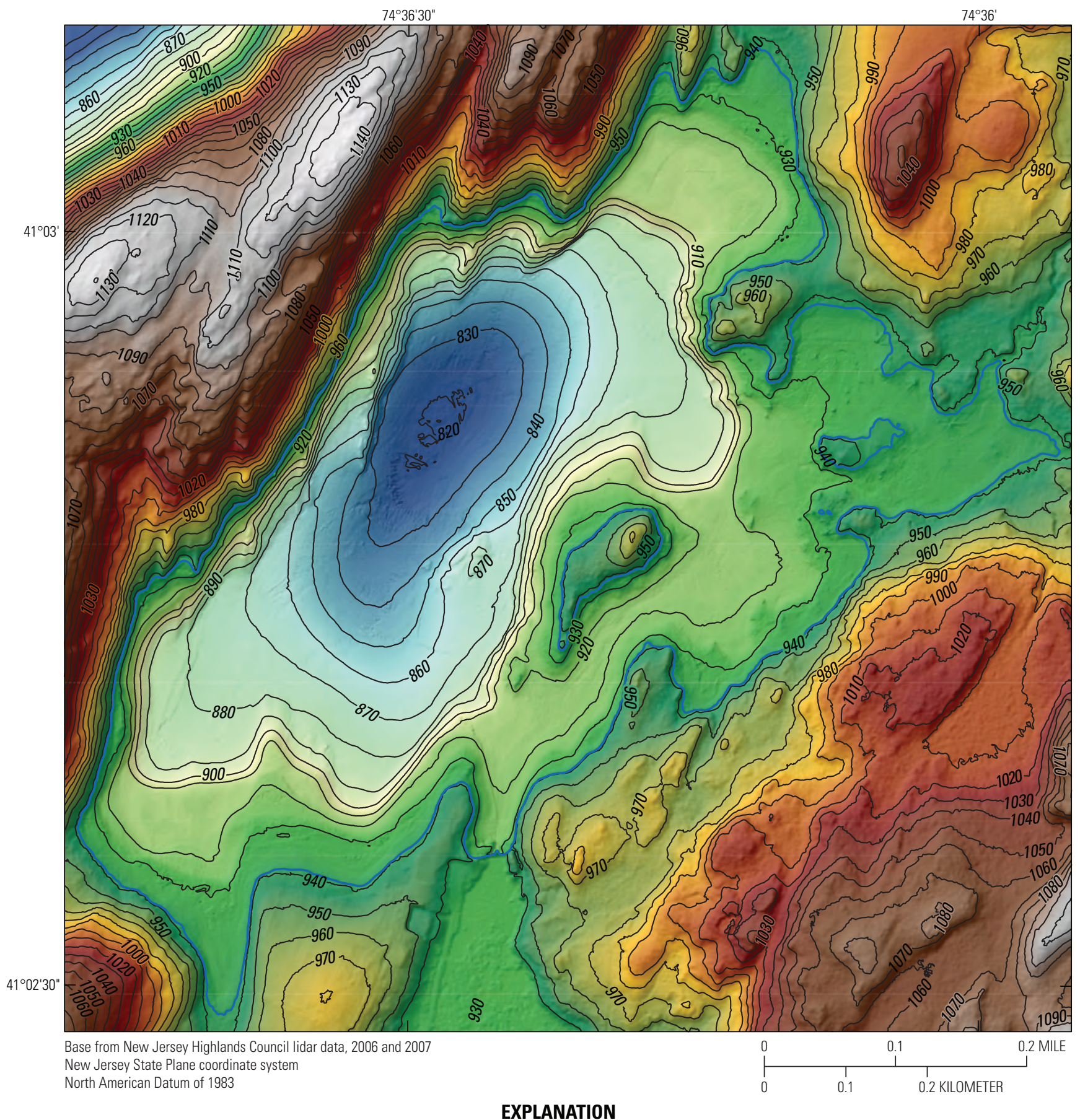

Elevation, in feet above North American Vertical Datum of 1988 1,150

985

938.39 (spillway elevation)

819

-10 - Depth contour-Contour interval 10 feet

Morris Lake boundary-Depth contour 0 feet deep

Figure 7. Mapped bathymetric elevations and elevation contours of Morris Lake (Newton Reservoir), New Jersey, and elevations of surrounding area. 
Table 2. Reservoir area and capacity at specified depths for Morris Lake (Newton Reservoir), New Jersey.

[Location of reservoir shown in figure 1. Expanded elevation-area-capacity table is available in Nystrom and Collenburg (2020); areas shown below are rounded to three significant figures. NAVD 88, North American Vertical Datum of 1988]

\begin{tabular}{ccccc}
\hline $\begin{array}{c}\text { Elevation, } \\
\text { in feet above NAVD 88 }\end{array}$ & $\begin{array}{c}\text { Depth below spillway, } \\
\text { in feet }\end{array}$ & $\begin{array}{c}\text { Capacity, } \\
\text { in million gallons }\end{array}$ & $\begin{array}{c}\text { Area, } \\
\text { in square miles }\end{array}$ & $\begin{array}{c}\text { Area, } \\
\text { in acres }\end{array}$ \\
\hline 938.39 & 0.00 & 1,980 & 0.226 & 145 \\
928.39 & 10.00 & 1,561 & 0.175 & 112 \\
918.39 & 20.00 & 1,231 & 0.135 & 86.4 \\
908.39 & 30.00 & 985.6 & 0.109 & 70.0 \\
898.39 & 40.00 & 765.5 & 0.102 & 65.1 \\
888.39 & 50.00 & 563.5 & 0.0909 & 58.2 \\
878.39 & 60.00 & 392.1 & 0.0725 & 46.4 \\
868.39 & 70.00 & 261.8 & 0.0526 & 33.6 \\
858.39 & 80.00 & 167.5 & 0.0393 & 25.1 \\
848.39 & 90.00 & 95.52 & 0.0297 & 19.0 \\
838.39 & 100.00 & 43.58 & 0.0201 & 12.9 \\
828.39 & 110.00 & 11.55 & 0.0105 & 6.75 \\
\hline
\end{tabular}

Table 3. Reservoir area and capacity at specified elevations for Morris Lake (Newton Reservoir), New Jersey.

[Location of reservoir shown in figure 1. Expanded elevation-area-capacity table is available in Nystrom and Collenburg (2020); areas shown below are rounded to three significant figures. NAVD 88, North American Vertical Datum of 1988]

\begin{tabular}{ccccc}
\hline $\begin{array}{c}\text { Elevation, } \\
\text { in feet above NAVD 88 }\end{array}$ & $\begin{array}{c}\text { Depth below spillway, } \\
\text { in feet }\end{array}$ & $\begin{array}{c}\text { Capacity, } \\
\text { in million gallons }\end{array}$ & $\begin{array}{c}\text { Area, } \\
\text { in square miles }\end{array}$ & $\begin{array}{c}\text { Area, } \\
\text { in acres }\end{array}$ \\
\hline 940.00 & -1.61 & 2,058 & 0.236 & 151 \\
930.00 & 8.39 & 1,621 & 0.181 & 116 \\
920.00 & 18.39 & 1,278 & 0.145 & 92.5 \\
910.00 & 28.39 & 1,023 & 0.111 & 70.9 \\
900.00 & 38.39 & 799.9 & 0.103 & 65.9 \\
890.00 & 48.39 & 594.4 & 0.0931 & 59.6 \\
880.00 & 58.39 & 417.0 & 0.0757 & 48.4 \\
870.00 & 68.39 & 280.0 & 0.0558 & 35.7 \\
860.00 & 78.39 & 180.9 & 0.0410 & 26.2 \\
850.00 & 88.39 & 105.8 & 0.0313 & 20.0 \\
840.00 & 98.39 & 50.59 & 0.0216 & 13.8 \\
830.00 & 108.39 & 15.35 & 0.0121 & 7.75 \\
820.00 & 118.39 & 0.03013 & 0.000858 & 0.549 \\
\hline
\end{tabular}

\section{Accuracy Assessment}

The accuracy of the mapped multibeam echosounder bathymetric data was evaluated using a quality assurance dataset collected with a single-beam echosounder, similar to methods described by Wilson and Richards (2006). A total of 9,386 quality assurance points was spatially joined with the mapped raster surface in a GIS and the measured elevations were compared (figs. 8 and 9) and descriptive statistics were calculated (table 4).
The National Standard for Spatial Data Accuracy, published by the Federal Geographic Data Committee (FGDC; 1998), defines a standard for assessing map accuracy based on the RMSE of the data. Assuming the errors are normally distributed, the vertical accuracy of the map product can be calculated at the 95-percent accuracy level as 1.96 times the RMSE. Because it is not possible to separate the effects of many different factors on each measured point in the dataset, this accuracy assessment includes the cumulative effects of many potential sources of errors or inaccuracies, including 


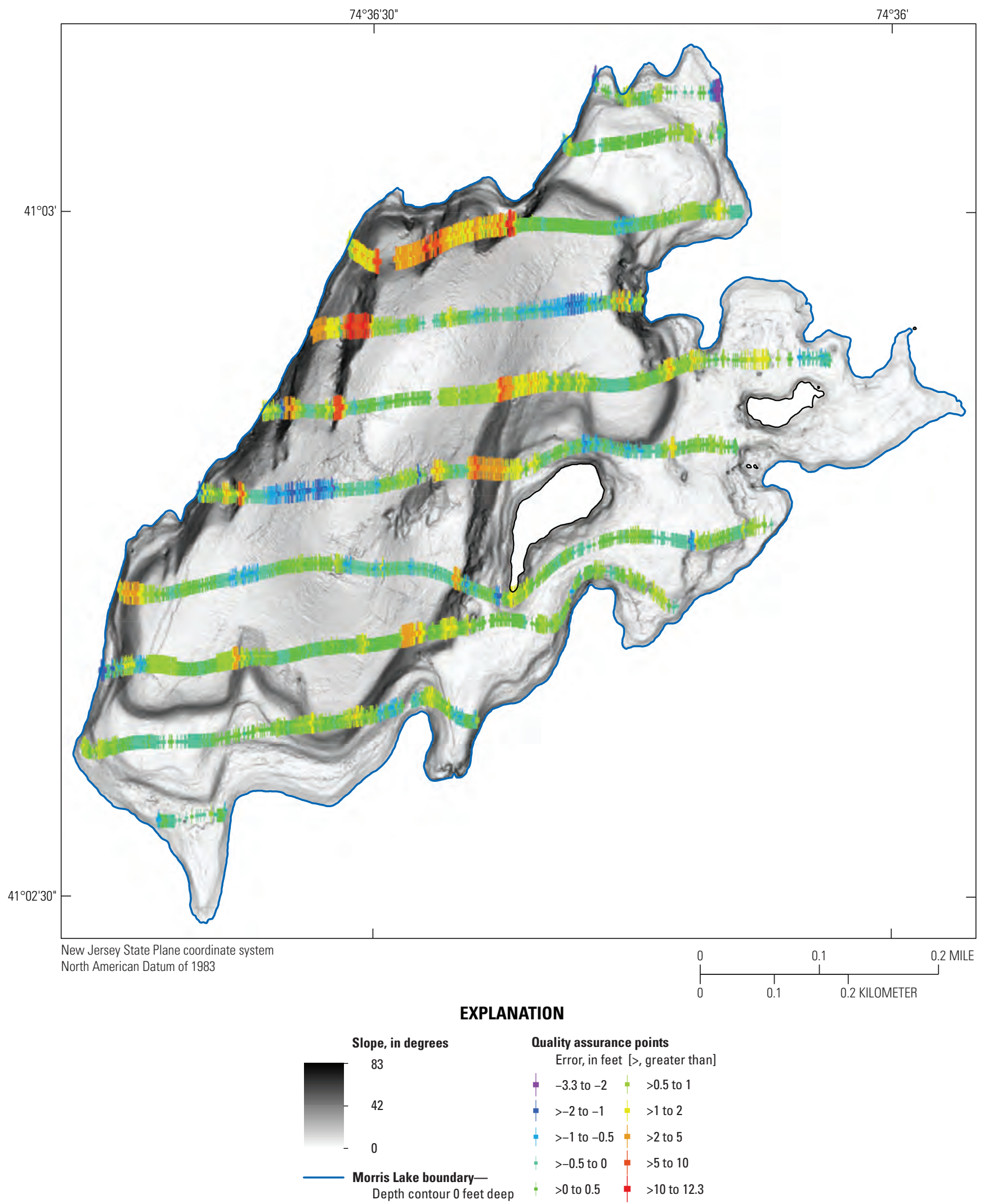

Figure 8. Quality assurance echosounder points compared to mapped elevation and slope of bathymetric surface, Morris Lake (Newton Reservoir), New Jersey. 


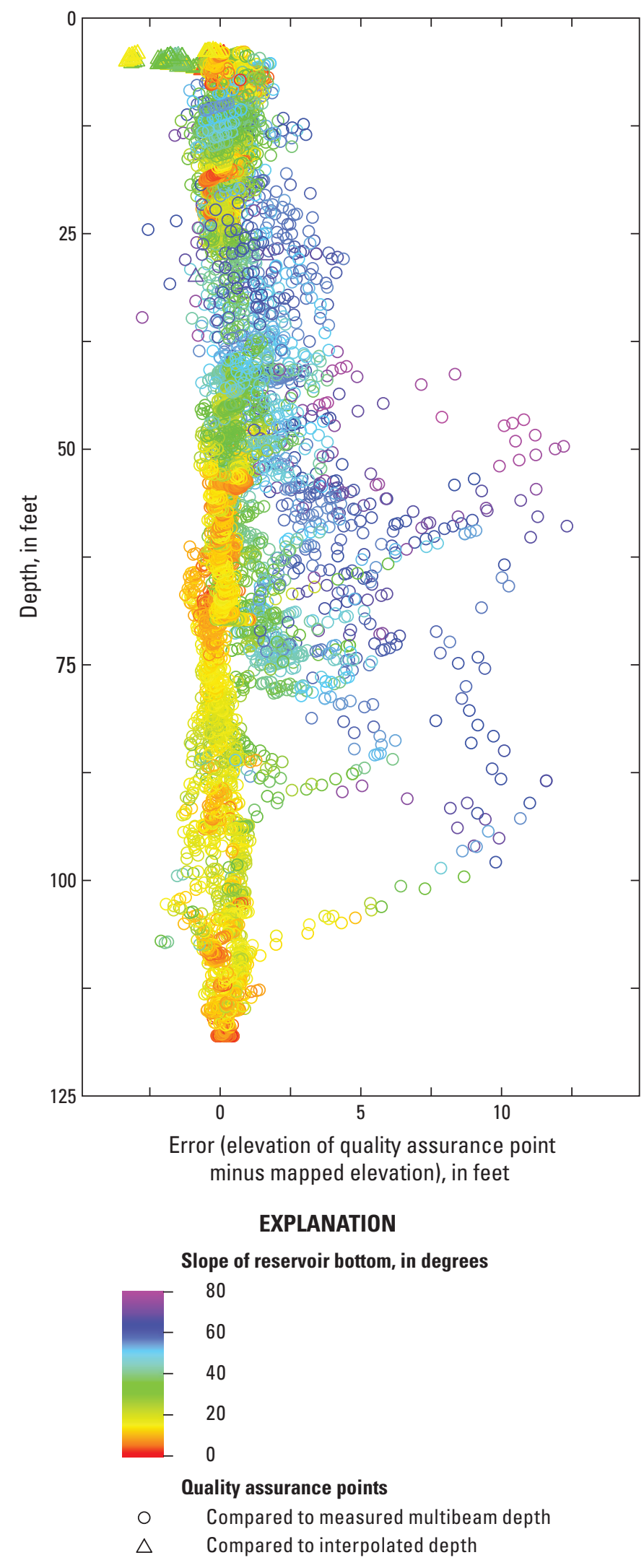

Figure 9. Results of comparison of quality assurance points and mapped surface by depth and slope. those associated with the measurements of depth, position, attitude of the boat (pitch, roll, heading, and heave), sound velocity, time synchronization errors, and other sources of measurement error.

Using the quality assurance dataset, errors were calculated by subtracting the multibeam echosounder mapped raster elevation from the measured single-beam echosounder point elevation. The median computed error was $0.23 \mathrm{ft}$, the median absolute error (the median of the absolute values of the computed errors) was $0.35 \mathrm{ft}$, and the 95 -percent accuracy (computed from the RMSE of the errors) was $2.68 \mathrm{ft}$ (table 4). Generally, the quality assurance elevations measured with the single-beam echosounder were about the same or slightly above (shallower than) the elevation measured with the multibeam echosounder (noted as positive errors in figs. 8 and 9).

The quality assurance points were categorized by location to determine the effects of interpolation and slope, and accuracy statistics were recomputed by category. The 95-percent accuracy of interpolated areas $(2.14 \mathrm{ft})$ tends to average slightly better than the overall accuracy $(2.71 \mathrm{ft}$; table 4) because most interpolated areas were shallow and fairly flat, and neighboring measured values provided close estimates of unmeasured areas. However, the largest negative errors (single-beam echosounder elevations slightly below [deeper than] multibeam echosounder elevations) were in the interpolated areas near the edges of the reservoir (fig. 9) and illustrate that interpolation using the lidar data was not accurate in all locations, likely as a result of the interpolation method. The accuracy statistics were also categorized by the slope of the mapped surface; in flat areas (slope 0 to 10 degrees) the 95 -percent accuracy was much better $(0.73 \mathrm{ft})$ than in extremely steep areas (slope 70 to 80 degrees) where the 95-percent accuracy was $11.67 \mathrm{ft}$. Large errors can easily occur in steep areas because even small errors in time synchronization, measurement of position and attitude of the boat, or position of the measured point within the mapped cell can result in large errors in measured depth. However, some of the calculated error in extremely steep areas may also result from the echosounder beam geometry and the incidence angle of the echosounder on the reservoir bottom. To measure depth, echosounders form acoustic beams that have some angular width; the single-beam echosounder used has a nominal width of 3 degrees (SyQwest, Inc., 2008) and the multibeam echosounder has nominal beam widths of 1.8 degrees (Teledyne Odom Hydrographic, 2019); some sound, though less than in the main portion of the beam, is also formed at angles away from the center of the beam (referred to as "side lobes"). In sloped areas, the acoustic beam will strike the bottom of the reservoir at an angle; since some width is inherent in the beam, part of the beam will strike the bottom (the leading edge of the beam) before other parts (the trailing edge of the beam; fig. 10). Depending on when the returned echo is loud enough to be digitized by the echosounder as the measured depth, this can result in a depth reading shallower, sometimes by several feet, than the depth directly under the center of the echosounder beam. Wider beam width, steeper slopes, and 
Table 4. Accuracy of point elevations of single-beam echosounder quality assurance points compared to mapped multibeam echosounder raster surface for Morris Lake (Newton Reservoir), New Jersey, bathymetric survey.

[Location of reservoir shown in figure 1. $\mathrm{n}$, number of points - each quality assurance point was compared to the corresponding elevation of mapped raster; $\mathrm{RMSE}_{\mathrm{z}}$, vertical root mean square error; Accuracy, National Standard for Spatial Data Accuracy fundamental vertical accuracy calculated at the 95-percent confidence level]

\begin{tabular}{lccccc}
\hline \multicolumn{1}{c}{ Area } & $\mathbf{n}$ & $\begin{array}{c}\text { Median error, } \\
\text { in feet }\end{array}$ & $\begin{array}{c}\text { Median absolute error, } \\
\text { in feet }\end{array}$ & $\begin{array}{c}\text { RMSE }_{\mathbf{z}^{\prime}} \\
\text { in feet }\end{array}$ & $\begin{array}{c}\text { Accuracy }_{\mathbf{z}^{\prime}} \text { 95-percent } \\
\text { confidence level, in feet }\end{array}$ \\
\hline Morris Lake & 9,386 & 0.23 & 0.35 & 1.37 & 2.68 \\
& & & & & \\
Measured areas & 8,870 & 0.26 & 0.35 & 1.38 & 2.71 \\
Interpolated areas & 516 & -0.31 & 0.42 & 1.09 & \\
& & & & & 0.73 \\
Slope 0 to 10 degrees & 2,621 & 0.09 & 0.23 & 0.37 & 1.09 \\
Slope 10 to 20 degrees & 2,639 & 0.16 & 0.29 & 0.56 & 1.15 \\
Slope 20 to 30 degrees & 1,394 & 0.22 & 0.33 & 0.59 & 2.58 \\
Slope 30 to 40 degrees & 1,013 & 0.51 & 0.75 & 1.32 & 3.24 \\
Slope 40 to 50 degrees & 665 & 0.90 & 0.99 & 1.65 & 4.95 \\
Slope 50 to 60 degrees & 724 & 1.30 & 1.30 & 2.53 & 8.85 \\
Slope 60 to 70 degrees & 265 & 2.56 & 2.56 & 4.52 & 11.67 \\
Slope 70 to 80 degrees & 65 & 3.99 & 3.99 & 5.95 & \\
\hline
\end{tabular}

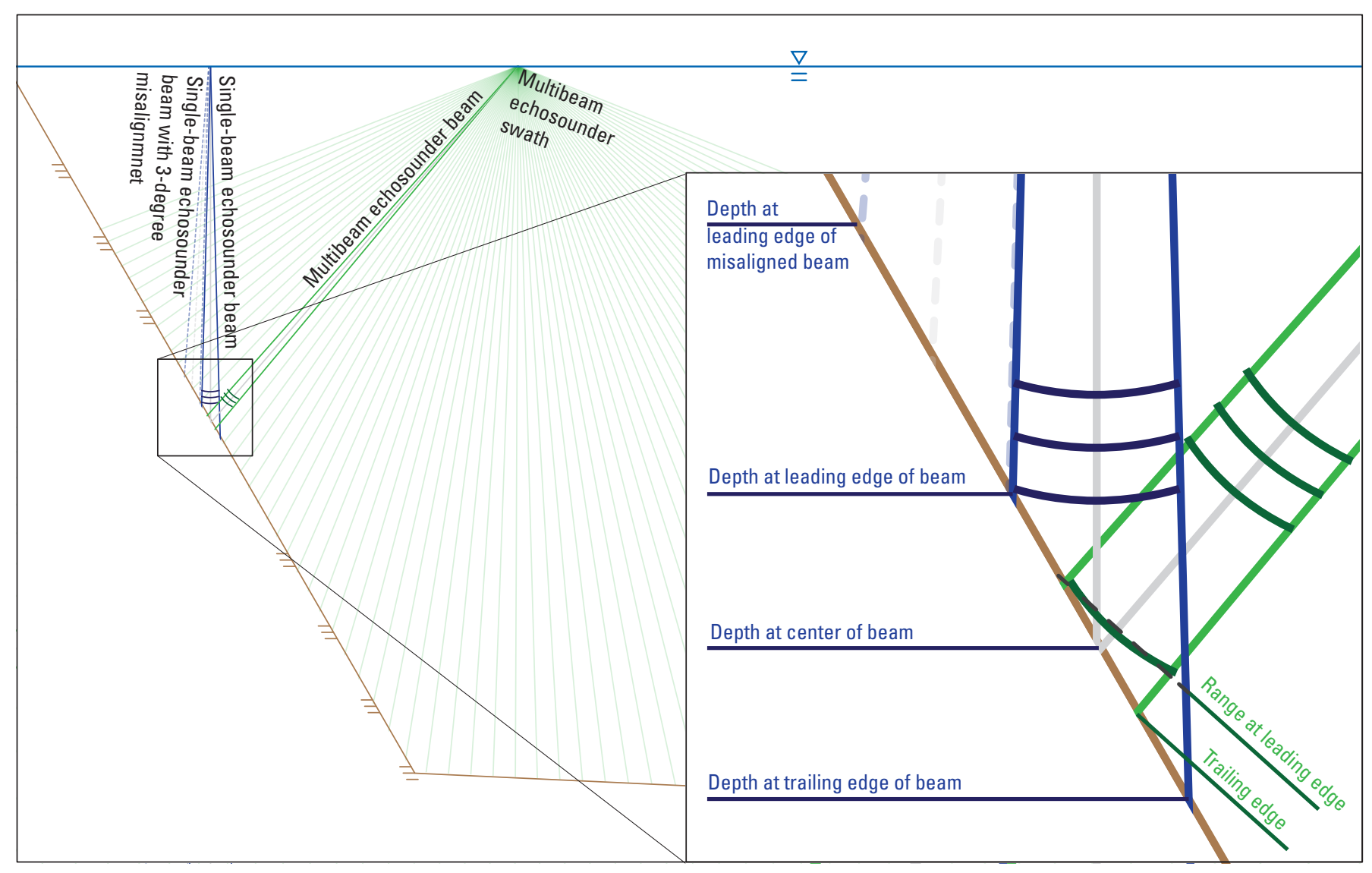

Figure 10. Echosounder beam geometry and potential cause of errors on steep slopes. 
deeper depths will all increase this shallow bias. To obtain the best return in the field from steep slopes, multibeam echosounder survey track lines are usually oriented parallel to the slope so that one edge of the swath (or fan) has beams hitting the slope more perpendicularly (fig. 10). In addition to the narrower beam width, this beam orientation relative to the slope can significantly reduce the shallow bias measured with the multibeam echosounder because there is less difference between when the leading edge and trailing edge of the beam strike the bottom. Furthermore, the real-time orientation of the single-beam is not measured as it is with the multibeam (with the INS), which may have introduced additional directional angle bias to the single-beam data, and would be exacerbated in high-slope areas (indicated with dashed lines in fig. 10). A shallow bias of the single-beam echosounder in steep areas can be seen by examining the sign of the errors and comparing the median error and the median absolute error. In flat areas ( 0 to 10 degrees slope), the median error was small $(0.09 \mathrm{ft})$ and the median absolute error was larger $(0.23 \mathrm{ft})$; however, in steep areas (slope 70 to 80 degrees), they were the same (both were $3.99 \mathrm{ft}$; table 4). Furthermore, the magnitude of the average signed error and average absolute error were the same (and not randomly distributed on either side of zero), which indicates that these errors likely at least partially reflect a shallow bias due to beam geometry.

\section{Summary}

A bathymetric survey of Morris Lake (Newton Reservoir) was conducted in April 2018 using a multibeam echosounder from a small moving boat. A quality assurance dataset was collected with a single-beam echosounder for comparison to the multibeam echosounder dataset. A Teledyne Odom MB2 multibeam echosounder with integrated inertial navigation system and real-time sound velocity measurement at the transducer head was used to collect multibeam data. A patch test was performed to calibrate and verify the performance of the inertial navigation system. Sound velocity profiles were measured to correct echosounder data for stratification with depth. The multibeam data were processed to include corrections for sound velocity, conversion of depth to elevation using a time series of water surface elevation, and to remove erroneous points. Following multibeam data processing and editing, 50,466,514 point observations remained for use in creation of a 3.3-foot (1 meter) raster grid. Light detection and ranging (lidar) data above the water surface elevation were used to supplement measured multibeam data. Bathymetric contours at 2-foot intervals of elevation and depth and an elevation-area-capacity table were computed from the raster grid. The bathymetric data and results are available as a USGS data release.
The results of the bathymetric survey indicate that the deepest part of Morris Lake is just over 119 feet and the average depth is 42 feet. Steep, rocky outcrops along the northwestern edge of the reservoir continue underwater, and slopes of more than 80 degrees are present in some areas of the reservoir; other areas of the reservoir are quite flat with slopes of less than 10 degrees. The capacity of the reservoir at full spillway level is 1,980 million gallons, and the reservoir has a surface area of 145 acres at the spillway elevation. The accuracy of the raster grid mapped with the multibeam echosounder was evaluated using a quality assurance dataset collected with a single-beam echosounder; 9,386 quality assurance points were spatially joined with the mapped raster surface in a geographic information system and the measured elevations were compared. The median computed error was 0.23 foot, the median absolute error was 0.35 foot, and the 95 -percent accuracy was 2.68 feet. Generally, the quality assurance elevations measured with the single-beam echosounder were about the same or slightly greater than the elevation measured with the multibeam echosounder. The accuracy in interpolated areas and measured areas was similar, but the interpolation using the lidar data was not accurate in all locations. The 95 -percent accuracy in flat areas ( 0.73 foot) was much better than the accuracy in extremely steep areas (11.67 feet). Large errors can easily occur in steep areas because of small errors in measurement of position and attitude, but some of the large calculated errors in steep areas likely result from the beam geometry of the single-beam echosounder.

\section{References Cited}

AML Oceanographic, 2010, Smart SV user manual (ver. 2.1, January 13, 2010): AML Oceanographic, 22 p., accessed October 5, 2016, at https://amloceanographic.app.boxenterprise.net/web_links/ 3328063/shared/a1qjym370915odho0683.

Applanix Corporation, 2017, POS MV V5 installation and operation guide, rev. 17: Richmond Hill, Ontario, Canada, PUBS-MAN-004291, 293 p.

Dickinson, S.M., 1899, The Sparks Manufacturing Company v. The Town of Newton et al., Reports of Cases Decided in the Court of Chancery of the State of New Jersey: Vol. XII: Trenton, N.J., The J.L. Murphy Pub. Co.

Esri, Inc., 2019, ArcGIS Desktop: Esri, Inc., software release, accessed February 20, 2019, at https://www.esri.com/en-us/ arcgis/products/arcgis-desktop/overview. 
Federal Geographic Data Committee, 1998, National standard for spatial data accuracy, part 3 of Geospatial positioning accuracy standards: Federal Geographic Data Committee, no. FGDC-STD-007.3, p. 3-1 to 3-25, accessed October 24, 2016, at https://www.fgdc.gov/standards/projects/accuracy/ part3/chapter3.

Huizinga, R.J., 2016, Bathymetric and velocimetric surveys at highway bridges crossing the Missouri River near Kansas City, Missouri, June 2-4, 2015: U.S. Geological Survey Scientific Investigations Report 2016-5061, 93 p., https://doi.org/10.3133/sir20165061.

Huizinga, R.J., and Heimann, D.C., 2018, Hydrographic surveys of rivers and lakes using a multibeam echosounder mapping system: U.S. Geological Survey Fact Sheet 2018-3021, 6 p., https://doi.org/10.3133/fs20183021.

HYPACK, Inc., 2019, HYPACK-Hydrographic survey and processing software: HYPACK, Inc., software release, accessed February 20, 2019, at http://www.hypack.com/ products/hypack.

KeyNetGPS, Inc., 2019, A Trimble VRS Network: KeyNet GPS website, accessed February 20, 2019, at http://www.keynetgps.com/.

Nystrom, E.A., and Collenburg, J.V., 2020, Geospatial bathymetry dataset and elevation-area-capacity table for Morris Lake (Newton Reservoir), New Jersey: U.S. Geological Survey data release, https://doi.org/10.5066/ P977GO3J.

OCM Partners, 2019, 2006 FEMA New Jersey flood mitigation lidar-Highlands area: National Oceanic and Atmospheric Administration National Centers for Environmental Information dataset, accessed February 21, 2019, at https://inport.nmfs.noaa.gov/inport/item/49853.
Rydlund, P.H., Jr., and Densmore, B.K., 2012, Methods of practice and guidelines for using survey-grade global navigation satellite systems (GNSS) to establish vertical datum in the United States Geological Survey: U.S. Geological Survey Techniques and Methods, book 11, chap. D1, 102 p. with appendixes.

SyQwest, Inc., 2008, Bathy-500MF multi-frequency survey echosounder: SyQwest, Inc. web page, accessed August 30, 2016, at https://www.syqwestinc.com/media/bathy-500mf/ bathy500mf-manual.pdf.

Teledyne, 2019, Teledyne PDS: Teledyne Marine software release, accessed February 20, 2019, at https://www.teledyne-pds.com/download/product_leaflets/ Multibeam\%20Survey\%20and\%20Processing-Charting _ product $\% 20$ leaflet.pdf.

Teledyne Odom Hydrographic, 2019, Teledyne Odom Hydrographic MB2, A Teledyne Odom hydrographic multibeam echosounder datasheet, accessed February 20, 2019, at http://www.teledynemarine.com/Lists/Downloads/ Teledyne\%20Odom\%20MB2\%20product\%20leaflet.pdf.

Teledyne RESON, 2019, SVP 70 Fixed-mount sound velocity probe: Teledyne RESON leaflet, 2 p., accessed February 20, 2019, at http://www.teledynemarine.com/Lists/Downloads/ SVP_70_\%20product\%20leaflet.pdf.

Wilson, G.L., and Richards, J.M., 2006, Procedural documentation and accuracy assessment of bathymetric maps and area/capacity tables for small reservoirs: U.S. Geological Survey Scientific Investigations Report 2006-5208, 24 p. plus oversize figs. [Also available at https://doi.org/10.3133/ sir20065208.] 
For more information about this report, contact: Director, New York Water Science Center U.S. Geological Survey

425 Jordan Road

Troy, NY 12180-8349

dc_ny@usgs.gov

(518) 285-5602

or visit our website at https://www.usgs.gov/centers/ny-water

Publishing support provided by the

Pembroke and Madison Publishing Service Centers 
